\title{
Molecular combing in the analysis of developmentally regulated amplified segments of Bradysia hygida
}

\author{
K.J.R. Passos ${ }^{1}$, S.Y. Togoro ${ }^{1}$, S. Carignon ${ }^{2}$, S. Koundrioukoff ${ }^{2}$, \\ A.-M. Lachages ${ }^{2}$, M. Debatisse ${ }^{2}$ and M.A. Fernandez ${ }^{1}$ \\ ${ }^{1}$ Departamento de Biologia Celular e Genética, \\ Universidade Estadual de Maringá, Maringá, PR, Brasil \\ ${ }^{2}$ Institut Curie, Centre de Recherche, \\ Centre National de la Recherche Scientifique, Unité Mixte de Recherche, \\ Paris, France
}

Corresponding author: M.A. Fernandez

E-mail: mafernandez@uem.br

Genet. Mol. Res. 11 (3): 2060-2070 (2012)

Received January 5, 2012

Accepted May 23, 2012

Published August 6, 2012

DOI http://dx.doi.org/10.4238/2012.August.6.10

\begin{abstract}
Molecular combing technology is an important new tool for the functional and physical mapping of genome segments. It is designed to identify amplifications, microdeletions, and rearrangements in a DNA sequence and to study the process of DNA replication. This technique has recently been used to identify and analyze the dynamics of replication in amplified domains. In Bradysia hygida, multiple amplification initiation sites are predicted to exist upstream of the BhC4-1 gene. However, it has been impossible to identify them using the available standard techniques. The aim of this study was to optimize molecular combing technology to obtain DNA fibers from the polytene nuclei of the salivary glands of $B$. hygida to study the dynamics of DNA replication in this organism. Our results suggest that combing this DNA without prior purification of the polytene nuclei is possible. The density, integrity, and linearity of the DNA fibers were analyzed, fibers 50 to $300 \mathrm{~kb}$ in length were detected, and a 9-kb fragment within the amplified region was visualized using
\end{abstract}


biotin detected by Alexa Fluor 488-conjugated streptavidin technique. The feasibility of physically mapping these fibers demonstrated in this study suggests that molecular combing may be used to identify the replication origin of the $B h C 4-1$ amplicon.

Key words: Molecular combing; Bradysia hygida; Replication origin; Developmentally regulated amplified segment

\section{INTRODUCTION}

Experimental models widely used to study the nature and structure of replication origins in metazoa are systems that exhibit developmentally regulated gene amplification. Some examples of this phenomenon include DNA segments that form DNA puffs in Sciaridae and the chorionic gene-containing chromosome segment in Drosophila melanogaster (Claycomb and Orr-Weaver, 2005). Examples of DNA amplification induced in vitro in cultured mammalian cells include the dihydrofolate reductase gene amplification in ovarian cells (Dijkwell et al., 1991; Altman and Fanning, 2004) and the adenosine monophosphate deaminase 2 gene amplification in Chinese hamster lung cells (Toledo et al., 1998; Anglana et al., 2003; Courbet et al., 2008). Gene amplification has also been reported to occur during the course of tumorigenesis in distinct chromosomal regions (Myllykangas and Knuutila, 2006).

In all of these systems, the replication origins of these amplicons are activated more than once during the cell cycle, resulting in additional copies in the genome. These additional copies are structured differently when they originate in cell culture than when they occur during tumorigenesis (Debatisse et al., 1993; Omasa, 2002; Myllykangas and Knuutila, 2006) or in developmentally regulated amplified segments (Claycomb and Orr-Weaver, 2005).

Despite the use of sophisticated methodologies, the identification of amplification initiation sites during DNA replication in metazoan systems has been difficult (Mesner and Hamlin, 2009), and the development of alternative technologies such as molecular combing has yielded better physical and functional mapping of such genome segments (Lebofsky and Bensimon, 2003).

In the molecular combing method (Bensimon et al., 1994), DNA molecules with a random-coil configuration are attached to a hydrophobic silanized cover slip by their extremities. The cover slip is removed from the solution at a constant speed of $300 \mu \mathrm{M} / \mathrm{s}$, resulting in the uniform extension and alignment of the DNA molecules owing to the force exerted by the receding air-water meniscus. Using this technique, the physical mapping of genomes and detection of target sequences can be performed (Bensimon et al., 1994; Lebofsky and Bensimon, 2003). The air-water meniscus exerts a constant perpendicular force on the attached DNA molecules, allowing for uniform orientation. The force exerted by the meniscus is sufficient to lengthen the DNA from its random-coil conformation but is insufficient to break the DNA extremity-cover slip surface interaction and the covalent bonds within the DNA molecules. Once in contact with air, the DNA molecules stick to the surface, preventing molecule retraction (Bensimon et al., 1994; Michalet et al., 1997; Lebofsky and Bensimon, 2003).

One of the major advantages of molecular combing is its capability for obtaining a high concentration of total genomic DNA without excessive breaking, which results in highdensity fibers with the majority of DNA fragments measuring 200-700 kb (Michalet et al., 
1997; Lebofsky and Bensimon, 2003). The high resolution of the combed DNA allows for the study of microdeletions (Michalet et al., 1997), amplifications (Herrick et al., 2000), and DNA rearrangements (Gad et al., 2001) via direct visualization of the rearranged genomic structures. Molecular combing can also be used to study the process of evolution (Koszul et al., 2004) and DNA replication (Lengronne et al., 2001; Norio and Schildkraut, 2001; Caburet et al., 2002; Lebosky and Bensimon, 2005). The feasibility of using molecular combing to identify and analyze the dynamics of replication during the developmentally regulated amplification of gene segments permits the use of a greater number of biological models in the study of DNA replication.

In D. melanogaster, the region comprising the chorion genes in the ovarian follicle cells has been shown to undergo gene amplification, and the DNA molecules obtained by this differential replication reportedly form an "onion skin" structure. Rhynchosciara americana, Sciara coprophila, and Bradysia hygida are members of the family Sciaridae in which specific regions of the genome are amplified in polytene cells of the salivary glands in the larvae (Claycomb and Orr-Weaver, 2005). Similar to chorionic gene amplification in D. melanogaster, gene amplification in B. hygida also forms an onion skin structure as a result of various levels of gene amplification in the DNA segments flanking the central region of amplification (Monesi et al., 1995).

Precise identification of the site of replication initiation for the amplified segments of the BhC4-1 gene of B. hygida using neutral-neutral (N/N) and neutral-alkaline (N/A) twodimensional gels was impossible, although the replication forks appeared to be upstream of the gene, suggesting the existence of a replication origin in this region (Coelho, 1997). Studies of this DNA segment have identified a region with numerous sites of bent DNA and a significant site localized to approximately $2000 \mathrm{bp}$ upstream of the BhC4-1 gene transcription start site (Fiorini et al., 2001). Sites of association with the nuclear matrix have also been identified in this segment (Mikami, 2000; Polinarski, 2005). The challenge of identifying the replication initiation site within this developmentally regulated amplification segment introduces difficulty into correlations with either the intrinsic bent DNA sites or the sites of association with the nuclear matrix in the BhC4-1 gene amplicon with replication initiation. Therefore, new strategies such as molecular combing are necessary to identify replication initiation sites in the amplified segment of the $B h C 4-1$ gene.

\section{MATERIAL AND METHODS}

\section{Biological material}

B. hygida (Diptera: Sciaridae) was described by Sauaia and Alves (1968). This sciarid was reared in soil at $22^{\circ} \mathrm{C}$ and fed a fermented mate diet supplemented with yeast extract. Under these conditions, the length of the sciarid life is approximately 36 days, of which 6 days comprise embryogenesis and 22 days comprise the larval development period. The larval instar is characterized by the occurrence of 3 rounds of molting that delimit 4th larval stages (Laicine et al., 1984; Silva and Fernandez, 2000). The pupal stage lasts for 5 days and culminates in the emergence of the adult, which lasts approximately 3 days from mating to egg laying, thus closing the cycle life. This sciarid has a pair of salivary glands that contain the polytene chromosomes (Sauaia, 1971) and can be divided into 3 distinct morphological regions called S1, S2, and S3 (Rizzo, 1980). 
The process of gene amplification in sciarids occurs during the last cycle of DNA replication in the salivary gland polytene chromosomes, and the DNA puffs occur exclusively at this location at the end of the fourth larval stage (Souza, 1999). B. hygida 4th-instar larvae develop 8 patterns of eyespots (E0 to E8) that provide markers for staging larval development and allow the distinction between the various puff patterns on the salivary gland polytene chromosomes (Sauaia, 1971).

\section{Dissection of salivary glands}

Salivary glands from 4th-stage larvae at ages E1, E3, and E7 were dissected using a stereomicroscope (Stemi DV4, Carl Zeiss). After gentle traction, the glands were separated from the fatty mass and stored at $4^{\circ} \mathrm{C}$ in $1 \mathrm{X}$ phosphate-buffered saline (PBS; $137 \mathrm{mM} \mathrm{NaCl}$, $2.7 \mathrm{mM} \mathrm{KCl}, 4.3 \mathrm{mM} \mathrm{Na}_{2} \mathrm{HPO}_{4}, 1.47 \mathrm{mM} \mathrm{KH}_{2} \mathrm{PO}_{4}, \mathrm{pH}$ 7.4).

\section{Analysis of DNA integrity and high molecular weight}

Extraction of high molecular weight DNA using agarose blocks was performed following a protocol described by Schurra and Bensimon (2009) with some modifications for our biological material. The glands were inserted into the plug mold (Bio-Rad) with a needle to avoid breaking and to maintain the integrity of the material. The molds were immediately filled with $1.5 \%$ low-melting-point agarose in $1 \mathrm{X}$ PBS at $42^{\circ} \mathrm{C}$ and incubated at room temperature for $15 \mathrm{~min}$ and then at $4^{\circ} \mathrm{C}$ for $30 \mathrm{~min}$. The digestion of agarose blocks was carried out in ESP solution [0.45 M ethylenediaminetetraacetic acid (EDTA), 1\% sarkosyl, and $2 \mathrm{mg}$ / $\mathrm{mL}$ proteinase $\mathrm{K}]$ at $50^{\circ} \mathrm{C}$ overnight and stored in $0.5 \mathrm{M}$ EDTA, $\mathrm{pH}$ 8.0. The blocks were visualized under a stereomicroscope before and after digestion with the ESP solution. The integrity and size of the DNA present in the agarose blocks were analyzed on $1 \%$ agarose gel in $0.5 \mathrm{X}$ TBE buffer (45 mM Tris-borate, $1 \mathrm{mM}$ EDTA, $\mathrm{pH}$ 8.0) using pulsed-field gel electrophoresis (PFGE) according to manufacturer instructions.

\section{Enzymatic digestion and staining}

The agarose blocks containing the samples were incubated twice in excess $(\sim 100 \mathrm{X}$ the agarose block volume) TE (10 mM Tris-HCl, $1 \mathrm{mM}$ EDTA, $\mathrm{pH} 8.0)$ with gentle agitation for $20 \mathrm{~min}$ and then digested with a rare restriction enzyme, NotI, in a final volume of $400 \mu \mathrm{L}$ that included the volume of the block ( $1 \mathrm{X}$ buffer, $0.1 \mathrm{mg} / \mathrm{mL}$ bovine serum albumin, $125 \mathrm{U} / \mathrm{mL}$ NotI; Biolabs) for $3 \mathrm{~h}$ at $37^{\circ} \mathrm{C}$. The blocks were then transferred to a tube containing $10 \mathrm{~mL} \mathrm{TE}$ and incubated for $15 \mathrm{~min}$ at room temperature to wash the blocks. This process was repeated twice. After washing with TE, each block was transferred to a 2-mL tube containing $250 \mu \mathrm{L}$ TE and $1 \mu \mathrm{L} 1 \mathrm{mM}$ YOYO $^{\circledR}-1$ iodide (Invitrogen) and incubated for $1 \mathrm{~h}$ in the dark (staining was also performed on some samples after the dissolution of the agarose blocks as described below).

\section{Agarose block melting}

Procedures that took place after staining with the fluorescent dye $\mathrm{YOYO}^{\circledR}-1$ were carried out in the dark. Each block was transferred to a tube containing $1 \mathrm{X} \beta$-agarase buffer (Bio- 
labs) in TE (final volume of $400 \mu \mathrm{L}$, including the volume of the agarose block), incubated for $15 \mathrm{~min}$ at $68^{\circ} \mathrm{C}$, and transferred to $42^{\circ} \mathrm{C}$ for $15 \mathrm{~min}$. For agarose digestion, $2.5 \mathrm{U} \beta$-agarase (Biolabs) was added to the sample and gently mixed. After incubating the solution for $1 \mathrm{~h}$ at $42^{\circ} \mathrm{C}$, another $2.5 \mathrm{U} \beta$-agarase was added and incubated overnight at $42^{\circ} \mathrm{C}$. The next day, 1.7 $\mathrm{mL}$ 0.25 M 2-(N-morpholino)ethanesulfonic acid solution (Sigma) was added and the sample was incubated for $30 \mathrm{~min}$ at $65^{\circ} \mathrm{C}$. The tube was then cooled for $2 \mathrm{~h}$ at room temperature and stored at $4^{\circ} \mathrm{C}$ in the dark for periods ranging from a few hours to 4 weeks.

\section{DNA processing on the molecular combing platform}

Before using the DNA, we incubated the tubes at room temperature for $30 \mathrm{~min}$ and transferred them to the equipment tank. The DNA was combed onto silanized cover slips according to manufacturer instructions (Genomic Vision), placed on slides with cyanoacrylate superglue (Loctite), and incubated at $60^{\circ} \mathrm{C}$ for $2 \mathrm{~h}$. The slides were then incubated at room temperature for $10 \mathrm{~min}$ and stored at $-20^{\circ} \mathrm{C}$ before in situ hybridization.

\section{Denaturation}

DNA fibers from B. hygida salivary glands (isolated from glands of larvae at ages E1, E3, and E7) obtained by molecular combing technology were denatured by immersion in $1 \mathrm{~N} \mathrm{NaOH}$ for 10 min. The reaction was stopped with rapid washing in $1 \mathrm{X}$ PBS at $4^{\circ} \mathrm{C}$ and subsequent washing in $1 \mathrm{X}$ PBS for 10 min with one exchange of buffer. The slides were then dehydrated with increasing ethanol concentrations (70,85, and 100\%) for 5 min in each bath. Slides prepared this way can be stored at $4^{\circ} \mathrm{C}$ until use.

\section{Hybridization}

For the hybridization, $1 \mu \mathrm{g}$ from the clones 4-kb EcoRI and 5-kb HindIII, which contain the initial sequence of the BhC4-1 gene and the downstream sequences, were linearized via digestion with EcoRI and HindIII (Biolabs), respectively, labeled with biotin using the BioNick Labeling System kit (Invitrogen), and purified on a G50 resin column (Roche). Hybridization was performed using $25 \mu \mathrm{L}$ hybridization solution/slide, which contained 50 ng each labeled DNA, $18 \mu \mathrm{L}$ hybridization buffer [10\% dextran sulfate, $50 \%$ formamide, $2 \mathrm{X}$ saline-sodium-citrate solution (SSC 2X, $300 \mathrm{mM}$ sodium chloride and $30 \mathrm{mM}$ trisodium citrate)], $1 \%$ Tween-20, and $0.2 \mathrm{mg} / \mathrm{mL}$ competitor genomic DNA (human Cot-1 DNA, Invitrogen). The slides were incubated at room temperature for $15 \mathrm{~min}$ and the hybridization solution (pre-incubated with the probes for $10 \mathrm{~min}$ at $37^{\circ} \mathrm{C}$ ) was placed on the slides, covered with a cover slip, and incubated for $5 \mathrm{~min}$ at $72^{\circ} \mathrm{C}$, then sealed and incubated at $37^{\circ} \mathrm{C}$ overnight in a humid chamber. After hybridization, the slides were washed 3 times, 5 min each wash, at room temperature with $50 \%$ formamide in $2 \mathrm{X} \mathrm{SSC}, \mathrm{pH} 5.6$, and then washed 3 additional times with $2 \mathrm{X}$ SSC, $\mathrm{pH} 7.0$, and once with $1 \mathrm{X}$ PBS.

\section{Immunodetection}

Twenty-five microliters of blocking solution (1.5\% blocking reagent [Roche] and $1 \mathrm{X}$ 
PBS with $0.05 \%$ Tween) was added to each slide, covered with a cover slip, and incubated for $30 \mathrm{~min}$ at $37^{\circ} \mathrm{C}$ in a humid chamber. After incubation, the cover slip was removed and the slide was washed 3 times with 1X PBS for 5 min each wash. This washing procedure was repeated between each incubation step with the fluorescent reagent or antibody. Samples were incubated for 30 min with $25 \mu \mathrm{L}$ of the first detection solution containing streptavidinAlexa Fluor 488 conjugate (Invitrogen) diluted 1:100 in blocking solution. After washing with PBS, as described above, the samples were incubated for 30 min with a $25-\mu \mathrm{L}$ second layer detection solution containing biotin-conjugated rabbit anti-streptavidin antibody (Rockland/ Tebu-bio) diluted 1:50 in blocking solution. The third and fifth detection layers were identical to the first layer described above, whereas the fourth was identical to the second layer. When the antibody incubations were complete, single-strand immunodetection was carried out using mouse anti-human single-stranded DNA antibody (Millipore) diluted 1:50 in blocking solution. Each sample was incubated with $25 \mu \mathrm{L}$ solution, covered with a cover slip, and placed in a humid chamber at $37^{\circ} \mathrm{C}$ for $30 \mathrm{~min}$. The second layer of detection was performed with goat anti-mouse-Cy5 (Abcam) diluted 1:100, and the third layer with donkey anti-goat-Cy5 (Abcam) diluted 1:100. After the last wash with 1X PBS, the slides were mounted with ProLong Gold antifade reagent (Molecular Probes).

\section{RESULTS AND DISCUSSION}

Systems that exhibit developmentally controlled gene amplification are potentially informative models for the study of mechanisms that regulate DNA replication and amplification. One such example is the formation of polytene chromosome DNA puffs in sciarid salivary glands. The molecular mechanisms involved in the control of DNA amplification are poorly understood, mostly owing to a lack of technologies for mapping functionally important elements in this process (Paçó-Larson et al., 2002). The combined use of N/A and N/N twodimensional electrophoresis methods in the analysis of replication intermediates in DNA puffs permits the identification of regions with bidirectional replication origins, which are active during the amplification process in the DNA II/A puff of S. coprophila (Liang et al., 1993) and in the C3 puff of R. americana (Yokosawa et al., 1999).

The N/A electrophoresis method was used for the analysis of an 11-kb segment containing the transcription unit of the BhC4-1 gene, which is amplified in the C4 puff of $B$. hygida. Using this technique, Coelho (1997) determined that the replication fork enters at the 5'-end of BhC4-1 and moves unidirectionally through a 4-kb DNA fragment comprising the promoter region of this gene. However, the precise site of amplification initiation of this amplified segment cannot be determined using N/N and N/A two-dimensional electrophoresis (Coelho, 1997). Therefore, the development and application of a new method are needed for the identification of replication origins in this sciarid.

The purity and molecular size of the DNA sample are critical features of the molecular combing procedure (Michalet et al., 1997). In the protocol developed for this study, the salivary gland nuclei were not purified before DNA isolation to reduce the loss and degradation of starting material. Complete dissolution of the B. hygida larva salivary glands in buffer containing proteinase $\mathrm{K}$ is a method widely used when studying this sciarid and is routinely used in DNA preparations for quantitative and qualitative analyses (Monesi et al., 1995).

Our aim was to evaluate whether this strategy could be used for DNA sample prepara- 
tion for molecular combing and thereafter to optimize the process to use less biological material and increase its efficiency. During salivary gland preparation from larvae of ages E1, E3, and E7, fat tissue was removed and the glands were incubated in 1X cold PBS. After dissection, the glands were immediately placed into PFGE molds and filled with low-melting-point agarose. The de-proteinization of glandular tissue was monitored using a stereomicroscope after incubation with ESP solution (Figure 1A and B).

\section{A}

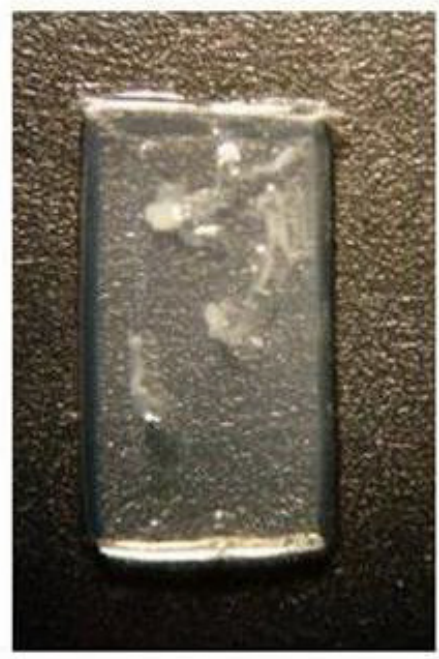

B

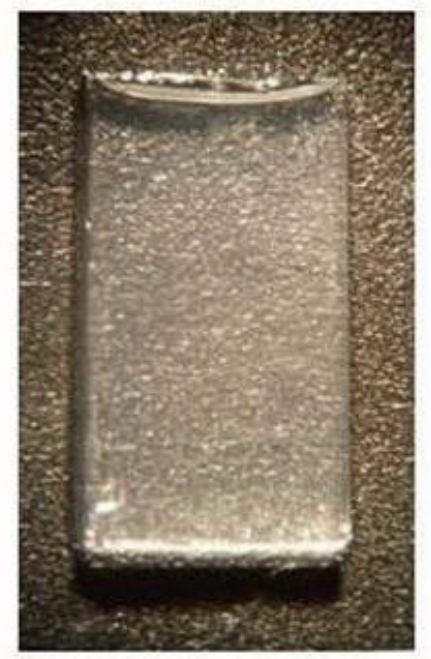

Figure 1. Bradysia hygida salivary gland agarose plugs. A. Agarose plug with salivary glands. B. Agarose plug with salivary glands digested with ESP solution.

Previous reports have stated that to prepare material for molecular combing of diploid cells, the optimal amount of DNA is obtained from 500,000 cells $/ 50 \mu \mathrm{L}$ low-melting-point agarose in the mold (Schurra and Bensimon, 2009). As each diploid mammalian cell has approximately $7 \mathrm{pg}$ DNA (Gregory, 2005), this protocol results in blocks containing approximately 3500 ng DNA each. Based on this information, the number of salivary glands necessary for each block can be calculated. On average, because each $B$. hygida salivary gland cell has approximately $2.55 \mathrm{ng}$ DNA and is composed of 100 cells, each pair of salivary glands has approximately 510 ng DNA (Paçó-Larson, 1976). Therefore, 6 pairs of glands yield 3060 ng DNA in an agarose block, which is approximately the amount required for the molecular combing technique. Our PFGE analysis confirmed that the direct preparation of DNA from B. hygida salivary glands yields high molecular size material suitable for use in the technique (data not shown).

After the digestion of the agarose blocks and their dissolution in appropriate buffer, the samples were used in the molecular combing process following a standard protocol (Michalet et al., 1997). The samples stored at $4^{\circ} \mathrm{C}$ were processed in separate batches based on the length of their storage (ranging from a few hours to 4 weeks). The appropriately combed DNA fibers were identified with fluorescence microscopy using $Y_{O Y O}{ }^{\circledR}-1$. No significant differences in fiber arrangement were found with respect to time of sample storage. By contrast, owing to the difference in the extent of amplification, the samples derived from the salivary gland at age E7 had a fiber density higher than that of samples from earlier larval ages (Figure 2). 


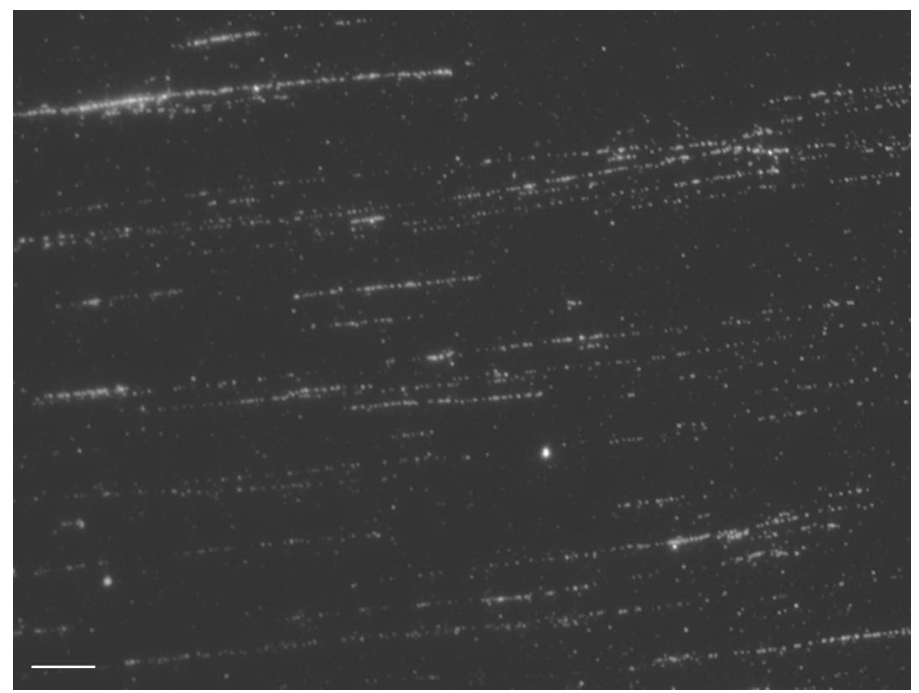

Figure 2. Bradysia hygida combed DNA array. Combed fibers from the salivary gland nuclei of E7 aged larvae were hybridized with mouse anti-ssDNA and detected with multiple layers of goat anti-mouse Cy5 and donkey anti-goat Cy5 antibodies. Bar $=5 \mu \mathrm{m}(10 \mathrm{~kb})$.

Our results indicate that the starting material must be doubled to obtain better results, even with the original DNA quantity of starting material we visualized DNA fibers ranging from 50 to $300 \mathrm{~kb}$ regardless of larval age (Figure 3). A series of slides representing samples of DNA fibers isolated from larvae of all ages was hybridized, and as expected, the BhC4-1 domain was easily located on the E7 samples (Figure 4).

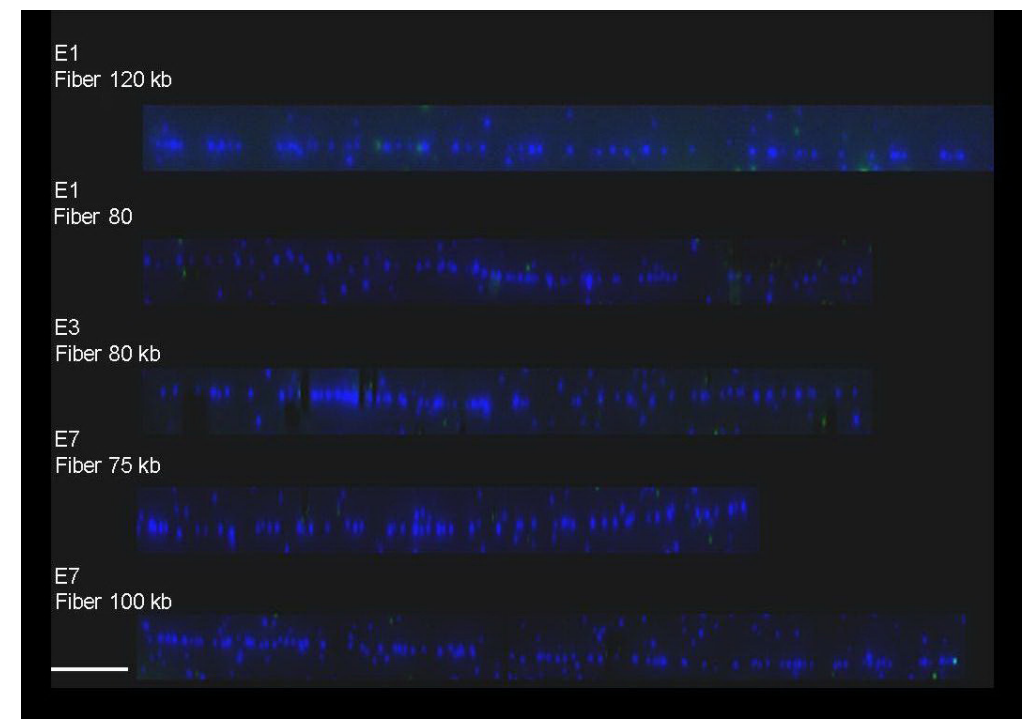

Figure 3. Bradysia hygida combed DNA fibers. The combed DNA fibers from the salivary gland polytene nuclei of E1, E3 and E7 larvae were hybridized with mouse anti-ssDNA and detected with layers of goat anti-mouse Cy5 and donkey anti-goat Cy5 antibodies. Bar $=5 \mu \mathrm{m}(10 \mathrm{~kb})$. 


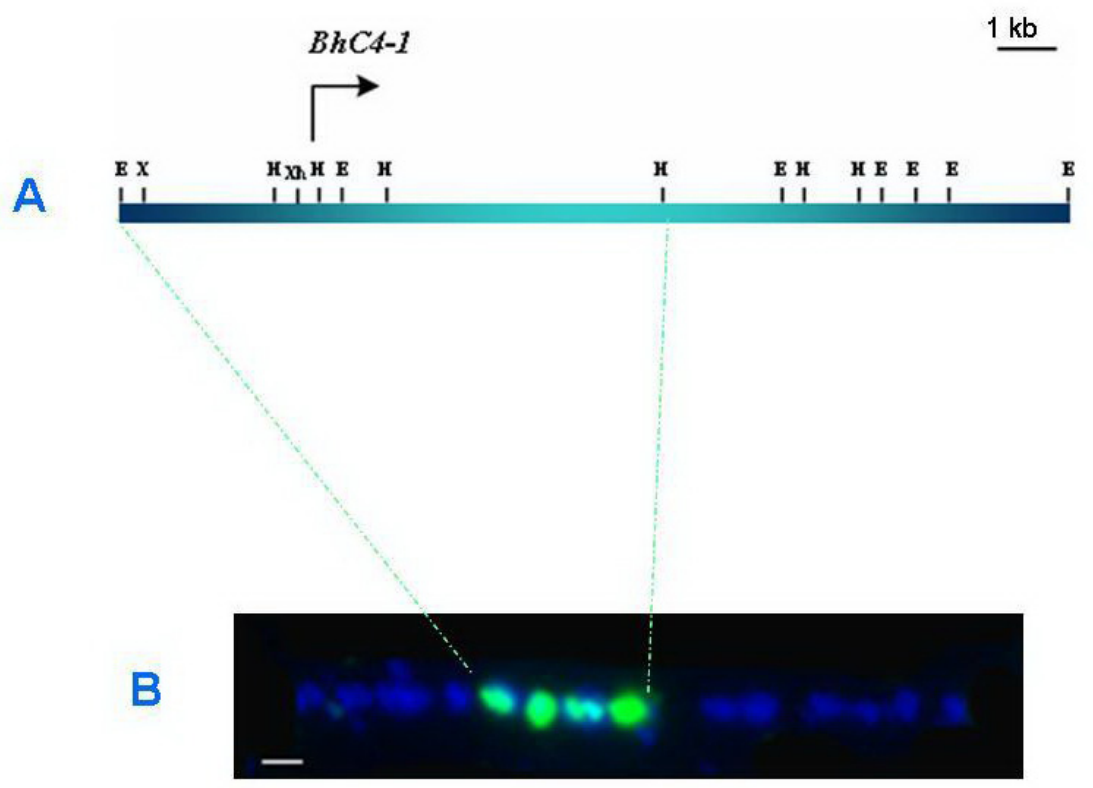

Figure 4. Combed BhC4-1 amplicon. A. Physical map from the 4-kb EcoRI fragment, which contains the initial sequence of the BhC4-1 gene, and the 5-kb HindIII segment, which includes the gene and downstream sequences. B. The combed fiber from salivary glands of E7 larvae was labeled with biotin and detected with fluorescein using routine methods. Bar $=1 \mu \mathrm{m}(2 \mathrm{~kb})$.

Our results also demonstrate the feasibility of preparing combed DNA samples without prior extraction of nuclei from B. hygida salivary glands. In samples prepared using this method, it will be possible to identify the sites of DNA replication initiation through fluorescent in situ hybridization using specific probes for the genomic region of interest combined with the detection of the incorporated halogenated nucleotides. Previous studies have reported the use of molecular combing technology for the analysis of DNA replication in D. melanogaster (Kolesnikova et al., 2009, 2010; Ivankin et al., 2011), but in contrast to the method implanted in this study, those procedures involved prior isolation of nuclei from the analyzed tissues.

\section{ACKNOWLEDGMENTS}

Research supported by grants from Fundação Araucária, Secretaria de Estado da Ciência, Tecnologia e Ensino Superior, FUNDO PARANÁ and the Academy of Sciences for Developing World. K.J.R. Passos received a graduate fellowship from Coordenação de Aperfeiçoamento de Pessoal de Nível Superior. We also thank Valmir Peron and Marli Licero Schuete Silva for their dedicated technical assistance and the Universidade Estadual de Maringá facilities (COMCAP laboratories).

\section{REFERENCES}

Altman AL and Fanning E (2004). Defined sequence modules and an architectural element cooperate to promote initiation at an ectopic mammalian chromosomal replication origin. Mol. Cell Biol. 24: 4138-4150. 
Anglana M, Apiou F, Bensimon A and Debatisse M (2003). Dynamics of DNA replication in mammalian somatic cells: nucleotide pool modulates origin choice and interorigin spacing. Cell 114: 385-394.

Bensimon A, Simon A, Chiffaudel A, Croquette V, et al. (1994). Alignment and sensitive detection of DNA by a moving interface. Science 265: 2096-2098.

Caburet S, Conti C and Bensimon A (2002). Combing the genome for genomic instability. Trends Biotechnol. 20: $344-$ 350.

Claycomb JM and Orr-Weaver TL (2005). Developmental gene amplification: insights into DNA replication and gene expression. Trends Genet. 21: 149-162.

Coelho PSR (1997). Análise dos Intermediários de Replicação do Pufe de DNA C4 de Bradysia hygida. Doctoral thesis, Faculdade de Medicina de Ribeirão Preto, Ribeirão Preto.

Courbet S, Gay S, Arnoult N, Wronka G, et al. (2008). Replication fork movement sets chromatin loop size and origin choice in mammalian cells. Nature 455: 557-560.

Debatisse M, Toledo F, de Saint Vincent RB and Buttin G (1993). Amplification of the Adenylate-Deaminase 2 and Linked Genes in Chinese Hamster Lung Fibroblasts. In: Gene Amplification in Mammalian Cells - A Comprehensive Guide (Kellens RE, ed.). Marcel Dekker Inc., New York, 173-183.

Dijkwel PA, Vaughn JP and Hamlin JL (1991). Mapping of replication initiation sites in mammalian genomes by twodimensional gel analysis: stabilization and enrichment of replication intermediates by isolation on the nuclear matrix. Mol. Cell Biol. 11: 3850-3859.

Fiorini A, Basso LR Jr, Paco-Larson ML and Fernandez MA (2001). Mapping of intrinsic bent DNA sites in the upstream region of DNA puff BhC4-1 amplified gene. J. Cell Biochem. 83: 1-13.

Gad S, Scheuner MT, Pages-Berhouet S, Caux-Moncoutier V, et al. (2001). Identification of a large rearrangement of the BRCA1 gene using colour bar code on combed DNA in an American breast/ovarian cancer family previously studied by direct sequencing. J. Med. Genet. 38: 388-392.

Gregory TR (2005). Animal Genome Size Database. Available at [http://www.genomesize.com]. Accessed July 30, 2012.

Herrick J, Michalet X, Conti C, Schurra C, et al. (2000). Quantifying single gene copy number by measuring fluorescent probe lengths on combed genomic DNA. Proc. Natl. Acad. Sci. U. S. A. 97: 222-227.

Ivankin AV, Koleniskova TD, Demakov SA, Andreenkov OV, et al. (2011). Analysis of DNA replication parameters in isolated organs of Drosophila melanogaster by molecular combing. Cell Tissue Biol. 5: 1-8.

Kolesnikova TD, Demakov SA, Ivankin AV, Andreenkova NG, et al. (2009). The mutation of the Suppressor of Underreplication gene does not affect the replication fork rate in the Drosophila melanogaster salivary gland polytene chromosomes. Dokl. Biochem. Biophys. 427: 175-178.

Kolesnikova TD, Demakov SA, Ivankin AV and Zhimulev IF (2010). Molecular combing in studies of the genome organization and DNA replication. Russ. J. Genet. 46: 1243-1246.

Koszul R, Caburet S, Dujon B and Fischer G (2004). Eucaryotic genome evolution through the spontaneous duplication of large chromosomal segments. EMBO J. 23: 234-243.

Laicine EM, Alves MA, de Almeida JC, Rizzo E, et al. (1984). Development of DNA puffs and patterns of polypeptide synthesis in the salivary glands of Bradysia hygida. Chromosoma 89: 280-284.

Lebofsky R and Bensimon A (2003). Single DNA molecule analysis: applications of molecular combing. Brief. Funct. Genomic. Proteomic. 1: 385-396.

Lebofsky R and Bensimon A (2005). DNA replication origin plasticity and perturbed fork progression in human inverted repeats. Mol. Cell Biol. 25: 6789-6797.

Lengronne A, Pasero P, Bensimon A and Schwob E (2001). Monitoring S phase progression globally and locally using BrdU incorporation in TK( $\left(^{+}\right)$yeast strains. Nucleic Acids Res. 29: 1433-1442.

Liang C, Spitzer JD, Smith HS and Gerbi SA (1993). Replication initiates at a confined region during DNA amplification in Sciara DNA puff II/9A. Genes Dev. 7: 1072-1084.

Mesner LD and Hamlin JL (2009). Isolation of Restriction Fragments Containing Origins of Replication from Comples Genomes. In: DNA Replication: Methods and Protocols (Vengrova S and Dalgaard JZ, eds.). Humana Press, New York, 315-328.

Michalet X, Ekong R, Fougerousse F, Rousseaux S, et al. (1997). Dynamic molecular combing: stretching the whole human genome for high-resolution studies. Science 277: 1518-1523.

Mikami LR (2000). Associação à Matriz Nuclear de Segmento à Montante do Gene BhC4-1 em Núcleo Politenico de Bradysia hygida. Master's thesis, Universidade Estadual de Maringá, Maringá.

Monesi N, Fernandez MA, Fontes AM, Basso LR Jr, et al. (1995). Molecular characterization of an $18 \mathrm{~kb}$ segment of DNA puff C4 of Bradysia hygida (Diptera, sciaridae). Chromosoma 103: 715-724.

Myllykangas S and Knuutila S (2006). Manifestation, mechanisms and mysteries of gene amplifications. Cancer Lett. 232: 79-89. 
Norio P and Schildkraut CL (2001). Visualization of DNA replication on individual Epstein-Barr virus episomes. Science 294: 2361-2364.

Omasa T (2002). Gene amplification and its application in cell and tissue engineering. J. Biosci. Bioeng. 94: 600-605.

Paçó-Larson ML (1976). Análise Quantitativa do Conteúdo de DNA da Glândula Salivar de Bradysia hygida. Master's thesis, Faculdade de Medicina de Ribeirão Preto, USP, Ribeirão Preto.

Paçó-Larson ML, Coelho PSC, Yokosawa J and Lara FJS (2002). Uso de Métodos de Eletroforese Bi-dimensional Neutroalcalina e Neutro-neutra para o Mapeamento Físico de Origens de Replição em Pufes de DNA. In: Hibridação de Ácidos Nucléicos (Lara FJS, ed.). $2^{\mathrm{a}}$ ed. Holos, Ribeirão Preto, 122-133.

Polinarski CA, Silva JL da C, Mikami LR and Fernandez MA (2005). Nuclear halo from Bradysia hygida (Diptera:Sciaridae) salivary gland polytene cells. Braz. Arch. Biol. Technol. 48: 351-357.

Rizzo E (1980). Descrição dos Pufes Cromossômicos da Glândula Salivar de Bradysia hygida (Díptera, Sciaridade). Master's thesis, Faculdade de Medicina de Ribeirão Preto, USP, Ribeirão Preto.

Sauaia H (1971). Cromossomas Politênicos de Bradysia hygida. Inibição do Desenvolvimento dos Puffs de DNA pela Hidroxiluréia. Doctoral thesis, Faculdade de Medicina de Ribeirão Preto, USP, Ribeirão Preto.

Sauaia H and Alves MAR (1968). A description of a new species of Bradysia (Diptera, Sciaridae). Pap. Avulsos Zool. 22: $85-88$.

Schurra C and Bensimon A (2009). Combing Genomic DNA for Structural and Functional Studies. In: The Nucleus (Ronald Hancock, ed.). Vol. 2. Humana Press, New York, 71-90.

Silva JLC and Fernandez MA (2000). Feulgen stain in heterogeneous egg samples from non-synchronized Bradysia hygida (Diptera:Sciaridae) laboratory culture. Cytologia 65: 167-171.

Souza JF (1999). Um Homólogo do Gene Dhr 38 é Expresso em Bradysia hygida (Díptera, Sciaridae) Durante o Final do Quarto Estádio Larval. Master's thesis, Faculdade de Medicina de Ribeirão Preto, USP, Ribeirão Preto.

Toledo F, Baron B, Fernandez MA, Lachages AM, et al. (1998). oriGNAI3: a narrow zone of preferential replication initiation in mammalian cells identified by 2D gel and competitive PCR replicon mapping techniques. Nucleic Acids Res. 26: 2313-2321.

Yokosawa J, Soares MA, Dijkwel PA, Stocker AJ, et al. (1999). DNA replication during amplification of the C3 puff of Rhynchosciara americana initiates at multiple sites in a $6 \mathrm{~kb}$ region. Chromosoma 108: 291-301. 